\title{
How Kizer healed the VA
}

\begin{abstract}
After Kenneth Kizer turned around the Veteran's Health Administration it was credited with providing the best medical care in the US. David Payne met him in London recently and heard how he pulled off such a reform, and about his past job taking on the tobacco giants
\end{abstract}

\author{
David Payne editor, bmj.com
}

BMJ, London WC1H 9JR, UK

In 1990 Kenneth Kizer clashed with the vice-president of the US Tobacco Institute, Brennan Dawson, on NBC's Today show after the state of California launched a multimillion dollar antismoking campaign.

The news clip (http://archive.org/details/tobacco_rgx27a00) includes a television advertisement in which industry executives cynically discuss the need to recruit 3000 new smokers each day to replace the 2000 Americans who quit and 1100 who die. A second advert shows a pregnant woman passive smoking.

Dawson warns Kizer, then director of health services for California, that America's tobacco farmers are a powerful lobbying group in Washington.

California's electorate, who had voted for 25 cents to be added to a pack of cigarettes to fund an antismoking campaign, had not sanctioned a $\$ 30 \mathrm{~m}$ ( $£ 19 \mathrm{~m}$; €23m) attack on the industry by Kizer's department. "Mudslinging doesn't go well with voters," Dawson told him.

But Kizer responded: "The only thing that's being attacked here is the image. Tobacco use isn't sexy or glamorous. One thing that's unique about our campaign is we've built in a very rigorous evaluation mechanism."

Over the next 20 years adult smoking rates in California dropped by $41 \%$ to $13.3 \%$. $^{1}$ Last year the rate fell to $11.9 \%{ }^{2}$

A 2010 paper in the journal Tobacco Control compared the change in smoking attributable cancer mortality rate (SACMR) in California with that in the rest of the US from 1979 to 2005 among adults aged 35 years or older. ${ }^{3}$ The study assessed deaths attributable to smoking from lung cancer (smoking causes $85 \%$ of lung cancer cases) and nine other cancers, including the oesophagus, stomach, pancreas, larynx, and lip, oral cavity, or pharynx. It found that California's mortality started to fall in 1984, seven years earlier than the rest of the US, and declined by $25.7 \%$ between 1979 and 2005, compared with $8.9 \%$ for the rest of the US.
"People still are amazed that the government would put stuff out like that," says Kizer referring to the television adverts he ran as director of health services. "Everyone was convinced when those aired that I would be immediately fired by George Deukmejian, who was a conservative Republican governor."

Kizer kept his job, and the campaign's high profile at a time of unprecedented change in California (the HIV epidemic, the embryonic environment movement), combined with launching a five a day nutrition campaign and running the country's largest Medicaid programme, inevitably bought him to the attention of the federal government.

\section{Federal challenge}

In 1994 President Clinton appointed Kizer, a former US Navy diver who had specialised in emergency care after graduating in medicine and public health, to lead the beleaguered Veterans Health Administration, part of the Department of Veterans Affairs, the second largest US government department.

First established after the first world war to provide treatment for veterans with combat related injuries and now the largest provider of healthcare services in the US, it was seen as centralised, punitive, and bureaucratic, as too hospital and specialty based, and with little focus on disease prevention and monitoring quality.

Colleagues warned Kizer that the cabinet level post was a "career ender," with elected officials queuing up to ridicule the department on CNN each time its failures hit the headlines.

But he argued that six years of delivering large scale change in California's large economy was an ideal preparation for life in the federal capital. "If there is any place that has politics that are similar to Washington, DC, it's Sacramento."

Kizer's 80 page Vision for Change integrated care strategy contained bold plans for service configuration and devolving greater accountability to the heads of 22 new integrated service networks across the country. Typically these consisted of 8-9 hospitals, 25-30 community clinics, 5-7 long term care facilities, 
10-15 counselling centres, and one or two residential care units for people with chronic mental health and substance misuse problems.

After he left in 1999, BusinessWeek said the Veterans Affairs system provided "the best medical care in the US." A later cover feature in Fortune magazine described "How the VA healed itself."

The media seized on the VA's technological reforms, particularly the extension of VistA (Veterans Health Information and Technology Architecture) and its computerised patient record system, across 172 hospitals in three years.

A patient barcode system helped to check dose timings and reduce prescription errors. Kizer also introduced a limited national formulary and tough price negotiations with drug companies.

An observational study published in the New England Journal of Medicine found that the VA outscored Medicare's fee for service programme for the quality of preventive, acute, and chronic care. $^{4}$

But service configuration was a bitter pill to swallow. It meant the closure of 29000 acute beds (55\% of the total) and the opening of 300 community clinics staffed by general internists. Inpatient admissions reduced by more than 350000 .

This month Kizer told an international summit on integrated care in London: "We reduced staffing but the proportion of caregivers increased. You have to restructure your assets, but hospitals are major employers in every community and when you talk about cutting jobs it causes elected officials' sphincters to tighten because hospitals are part of a community's identity."

Kizer experienced this first hand after four years when he sought reconfirmation for his job. One senator demanded an assurance that the VA would never close a local hospital, an assurance he felt unable to provide. Another supported him privately but said he could not endorse him publicly.

Ultimately a law was passed that kept Kizer in post for a further year, but by then he decided to leave for personal reasons and was keen to set up and lead the National Quality Forum, which had been recommended by a presidential commission to set and endorse standards of care using a formal consensual process. He stayed for six years.

After heading so many organisations, how would he describe his leadership style? "I always have a hard time answering, but I think most people find I solicit input broadly.

"I expect people to be brutally honest and tell me why things won't work. And then I'll make the decision. I tend to be fairly aggressive, particularly as far as timelines and moving things forward.

"I try to cut through the clutter and get to the essence of the problem. I think everyone would agree I'm willing to take substantial risks. I try to avoid taking stupid or poorly informed risks, but I have no problem going way out on a limb."

\section{Patient safety}

At the VA Kizer also encouraged colleagues to report errors but was warned by his boss that going public on them was "political suicide."

Kizer adds: "He said you have to understand that if you move forward, you'll be the first casualty if things don't go well.

"We did report on our errors and collected 19 months' worth of data, which showed that there were about 3000 errors in the system and then 700 preventable deaths over that 19 month period. And we put it in a report and sent it to Congress.

“It was an unsolicited report; we didn't have to do it. To my amazement nothing happened."

Six months later he got a call from Robert Pear, Washington correspondent for the New York Times. Pear said he'd heard about the report, asked if it existed, and assumed he would have to submit a freedom of information request to get a copy.

"I told him to drop by that night and I'd give him a copy, but we needed to talk about it to put it into some context. So we talked for about two hours," says Kizer.

On Monday the newspaper led on the story with a typically hard hitting but factually accurate story written by Pear.

"The key point I wanted to make sure that Robert got was that as bad as this was, this is what was happening in hospitals every day, everywhere around the country. And the difference was that the VA was doing something about it.

"Instead of basically brushing it under the rug, we were overtly trying to do something about it. And a couple of days later there was a nice glowing editorial. It was a risky thing to do. It turned out OK. As a matter of fact I think it turned out better than OK."

Competing interests: The author has completed the ICMJE unified disclosure form at www.icmje.org/coi_disclosure.pdf (available on request from the corresponding author) and declares no support from any organisation for the submitted work; no financial relationships with any organisation that might have an interest in the submitted work in the previous three years; and no other relationships or activities that could appear to have influenced the submitted work.

Provenance and peer review: Commissioned; not externally peer reviewed.

Smoking rates in California continue to decline as calls to the state's quit line reach record highs. Medical News Today 2009 Apr 11. www.medicalnewstoday.com/releases/145621. php.

2 California Department of Public Health. California adult smoking rate reaches historic low. Press release, 13 July 2011. www.cdph.ca.gov/Pages/NR11-031.aspx.

3 Cowling, D, Yang HJ. Smoking-attributable cancer mortality in California, 1979-2005 Tob Control 2010;19:i62-7.

4 Jha AK, Perlin JB, Kizer KW, Dudley RA. Effect of the transformation of the Veterans Affairs health care system on the quality of care. N Engl J Med 2003;348:2218-27.

Cite this as: BMJ 2012;344:e3324

(c) BMJ Publishing Group Ltd 2012 